with the Adiniralty where he became a leading authority on the recog.ition of fishing craft, writilg a series of books of refierence for the services on fishirig craft, first on those of western Europe and then on those of far eastern countries.

In 1946 Rees was appointed to the sciontific staff of the British Museum (Natural History) ard for the next eight years was in charge of the molluse section. During this time he published important pupers, ehiefly on the Cephalopod $i$, beirg specially interusted in giant squids, and he made very interesting investigations on the larval stages of the octopus in the English Channel. He also did sound work oil heteropods and terrestrial gastropods including a report for the Colonial Office on the giant snail, Achatina. He reviewed the breathing devices of terrestrial pulmonates and wrote on the aerial di persion of Mollusca. He did not, howevor, conceal his eagerness to return to work on the coelenterates and when the opportunity arose in $\mathbf{1 9 5 4}$ he was transferred to the coelenterate section as a principal scientific officer and was able to resume his researches on the Hydiomedusae. He d d not, however, abandon his interest in the mollusca and was president of the Malacological Society fiom 1963 to 1966.

Rees pursued his studes in many marine laboratories in Europe and latterly in the United States, and in addition to discover ing a number of new species of hydroid was often succossful in linking for the first time a known medusa to its hydroid, which was often known by a different name. His interest in the classification of the Hydrozoa culminated in an international symposium on "Cnidaria and their Evolution", which was effectively organized and edited by him for the Zoological Society of London.

J. P. Harding

\section{Dr P. D. F. Murray}

Dr P. D. F. Murray died suddenly on May 17 on board ship while on his way from Australia to Cambridge. He was one of Australia's most distinguished zoologists.

Murray was born on June 18, 1900, at Dorchester. $\mathrm{He}$ went to Australia at an early age and was educated at Riverview College and the University of Sydney, from which he graduated with first class honours and the university medal in zoology. He was awarded the Macleay Fellowship of the Linnean Society of New South Wales and began research work for which he was awarded the DSc. After staying for a few years as lecturer, he left Sydney and spent some time at the Universities of Freiburg and Oxford before taking up a Royal Society Smithson Research Fellowship at the Strangeways Laboratory at Cambridge. In 1936 he was appointed university demonstrator at Bedford College and three years later reader in biology and comparative anatomy at the Medical College of St. Bartholomew's Hospital.

In 1949 the Challis chair in zoology in the University of Sydney became vacant and Murray returned to take up this appointment. Ill health, however, forced him to relinquish it and in 1960 he went to the University of New England at Armidale in New South Wales, where he had been appointed reader in zoology. This position enabled him to pursue his research without the heavy load of administration that had undermined his health in Sydney. He retired from this post last year and the university honoured him by appointing him an honorary research fellow.

Besides holding the degrees of the University of Sydney, Murray also held a BSc from the University of Oxford and an honorary MA from Cambridge. When the Australian Academy of Science was established he became one of the Foundation Fellows.

Murray's research interests were in the field of experimental embryology and morphogenesis. While still at the University of Sydney early in his career he carried out work on the development of single somites, of unsegmented mesoderm and of the skeleton in chick embryos.
He used the technique of chorio-allantoic grafts, which, together with tissue cultures, became his major tech. niques in his later work.

After he left Sydney, Murray continued his research with studies on the development of the heart and the blood vessels and the effects of various cations on the heartbeat and the fibrillation in the developing chick heart. Later he concentrated on experimental studies of the skeletal tissues and during the past few years worked on the histology and the experimental induction of adventitious cartilage.

His research interests, however, do not tell the full story of Murray's role in academic life. He was a man of great modesty but of firm purpose. His clear mind and wide interests in many facets of biology, his integrity and disinterestedness, were generally acknowledged and caused his advice to be sought on many occasions. And because his taking up the position of professor of zoology came at the beginning of a rapid expansion of university teaching with the establishment of new institutions the calls on his advice, his time and his energy were many.

When he took up the readership in the University of New England he was freed from many of the more arduous tasks of administration. He could again concentrate on his research work and the supervision and stimulation of work of younger colleagues. On his retirement he looked forward with keen anticipation to a renewal of old friendships at the Strangeways Laboratory, where he intended to spend the next two years. His sudden death, depriving the world of an outstanding scientist, is therefore the more poignant and tragic.

Alex STOCK

\section{Professor Carl Kling}

Professor Carl Kling died in July at the age of 88 . $\mathrm{He}$ became interested in microbiology as a medical student, and after graduation joined the staff of the Swedish National Bacteriological Laboratory. He was appointed director in 1924 and held this post until his retirement in 1945.

In 1911 Sweden experienced what was to develop into one of the most devastating poliomyelitis epidemics ever recorded. Klirg dedicated himself to a study of the epidemiology of the disease and developed an almost obsessive interest in this subject which stayed with him for the rest of his life.

His most significant contribution came in 1929 when, after observations on several European epidemics and a re-evaluation of earlier laboratory findings, he concluded that poliomyelitis must indeed be an intestinal infection. This represented a radical departure from the generally accepted concept of poliovirus as an exclusively neurotropic agent. It took almost ten years and a great deal of confirmatory evidence to convince the medical world that Kling's ideas were essentially correct.

His hypothesis when first presented had rested partly on his intuition and power of scientific imagination. In the following years, in experimental studies of the patho. genesis and epidemiology of the disease, he added much of the substantial evidence that finally revolutionized the concepts of the natural history of poliomyelitis.

In later years he engaged himself in a less fruitless search for extrahuman virus reservoirs. He remained active long after his retirement; only in his last two years did age begin to dampen his spirits.

Under Kling's directorship the National Bacteriological Laboratory grew to acquire both national and international recognition and long served as Sweden's contral breeding place for the microbiological sciences. This development did not take place entirely without controversy. With his refreshingly nonconformist attitude to both life and science, Kling made a few enemies as well as many dovoted friends. With him Swedish medical science has lost one of its most colourful personalities. SVEN GaRD 